Published by Al-Nahrain College of Medicine P-ISSN 1681-6579

E-ISSN 2224-4719

Email: iraqijms@colmed-alnahrain.edu.iq http://www.colmed-alnahrain.edu.iq http://www.iraqijms.net

\title{
Assessment of Serum Zinc Level in Patients with Polycystic Ovary Syndrome
}

\author{
lqbal G. Farhood FICMS (D\&V) \\ Section of Dermatology \& Venereology, Dept. of Medicine, College of Medicine, Al-Nahrain University, Baghdad, Iraq
}

\begin{abstract}
Background

Objective

Methods
\end{abstract}

Results

Conclusion

Keywords

Citation

Polycystic ovary syndrome (PCOS) is the most common endocrine-metabolic disorder affecting women of reproductive age characterized by multiple hormonal imbalances, reflecting on a clinical presentation dominated by manifestations of hyperandrogenism, which generate short and long term consequences on female health. Skin is a major target for androgen activity, several hyperandrogenemia-triggered dermatologic alterations can be seen in PCOS, most commonly hirsutism, androgenic alopecia, acne, seborrhea, onycholysis, and onychorrhexis. Zinc is one of the most important trace elements required as a catalytic, structural, and regulatory ion for the activities of more than 300 enzymes, proteins, and transcriptional factors. Zinc insufficiency in the female can lead to complications such as impaired synthesis/secretion of follicular stimulating hormone (FSH) and luteinizing hormone (LH), abnormal ovarian development.

To assess serum zinc level in patients with PCOS.

A case-controlled study was conducted in Al-Imamein Al-Kadhemein Medical City from the period of March to June 2016. Eighty females were enrolled in this study; their age ranged from 20 to 32 years. They were divided into 4 groups: Group I: Twenty patients with PCOS with body mass index (BMI) ranged from 30.0-40.0. Group II: Twenty normal healthy control obese ladies with BMI ranged from 30.0-40.0. Group III: Twenty patients with polycystic ovary syndrome with BMI ranged from 18.5-29.9. Group IV: Twenty females as a healthy control non-obese ladies with BMI ranged from 18.5-29.9.

Serum zinc level was significantly decreased in obese PCO group than in non-obese PCO group. Serum prolactin (PRL) level and LH levels were elevated in PCO group which was highly significant. There was negative correlation between serum zinc level and BMI in PCO patients. Also, negative correlation was observed between serum zinc level and serum PRL level in non-obese PCO patients. Serum zinc level reduced in obese PCOS than in non-obese PCO.

Serum zinc level, polycystic ovary syndrome

Iqbal G. Farhood. Assessment of serum zinc level in patients with polycystic ovary syndrome. Iraqi JMS. 2017; Vol. 15(1): 39-47. doi: 10.22578/JJMS.15.1.6

List of abbreviation: $\mathrm{BMI}=$ Body mass index, $\mathrm{FSH}=$ Follicle stimulating hormone, IR = Insulin resistance, $\mathrm{LH}=$ Luteinizing hormone, $\mathrm{PCOS}=$ Polycystic ovary syndrome, $\mathrm{PRL}=$ Prolactin

\section{Introduction}

$\mathrm{P}$ olycystic ovary syndrome (PCOS) is the most common endocrine-metabolic disorder affecting women of reproductive age characterized by multiple hormonal imbalances, reflecting on a clinical presentation dominated by manifestations of hyperandrogenism, which generate short and long term consequences on female health ${ }^{(1)}$.

It is a common endocrinopathy affecting $6-10 \%$ of reproductive aged women (2), with a prevalence ranging from $5-10 \%$ in the general 
population and almost $30 \%$ among obese women ${ }^{(3)}$.

It is multi-factorial, with complex genetic and endocrine disorder; this heterogeneity seems to be modulated by multiple factors, such as prenatal androgen exposure, nutritional status in the uterus, genetic factors, as well as ethnicity, insulin resistance of puberty and/or exaggerated adrenarche and changes in body weight. Environmental factors, such as obesity, appear to exacerbate the underlying genetic predisposition. It is characterized by menstrual disturbances, clinical and biochemical manifestations of hyperandrogenism, ovulatory dysfunction and polycystic ovaries (4).

PCOS is associated with an approximately 7fold increased risk of type 2 diabetes mellitus (5). Insulin resistance (IR) and pancreatic $\beta$ cell dysfunction are major risk factors for the development of type 2 diabetes mellitus. Defects in insulin action and insulin secretion are critical determinants in the pathogenesis of glucose intolerance in PCOS and both are influenced by genetic and environmental factors ${ }^{(6)}$.

PCOS is manifested by abdominal obesity, insulin resistance, dyslipidemia, and endothelial dysfunction. Central adiposity appears to play an important role in the metabolic phenotype through the production of various adipocyte-derived cytokines and proteins known as adipokines (7). Furthermore, PCOS has been described as a state of chronic low-grade inflammation mainly characterized by a modest rise in serum C-reactive protein compared to the weight matched controls (8).

Because skin is a major target for androgen activity, several hyperandrogenemia-triggered dermatologic alterations can be seen in PCOS, most commonly hirsutism, androgenic alopecia, and acne and also seborrhea, onycholysis, and onychorrhexis (9).

Hirsutism: is defined as the presence of excessive terminal hair in areas of the body that are androgen dependent and usually hairless or with limited hair growth such as the face, chest, areolas, abdomen, and upper thighs ${ }^{(10)}$. Although hyperandrogenemia is the trigger for hirsutism, the rate of hair growth is not proportional to the degree of hyperandrogenism ${ }^{(11)}$.

Acne and Seborrhea: Sebaceous glands are also androgen-dependent structures, with adipocytes being highly sensitive to androgen signaling, which is exacerbated in PCOS, leading to the development of acne and seborrhea (12). Androgenic Alopecia: is a disorder in which, hair is miniaturized, due to an increased telogen:anagen ratio "with telogen hair being at mitotical rest and anagen hair being mitotically active" and associated to genetic susceptibility related to increased $5 \alpha$-reductase activity in the hair follicle. This increased enzymatic activity would favor the local conversion of testosterone into dihydrotestosterone, a more powerful androgen (13).

The diagnosis of PCOS is based on the Rotterdam criteria ${ }^{(14)}$ with women satisfying at least two of the following three criteria:

1) oligomenorrhea/oligoovulation

2) clinical or biochemical hyperandrogenism

3)polycystic ovaries on ultrasound examination.

Zinc is one of the most important trace elements required as a catalytic, structural, and regulatory ion for the activities of more than 300 enzymes, proteins, and transcriptional factors ${ }^{(15)}$. Therefore, zinc is a key element in many homeostatic responses of the body, including oxidative stress and in many biological functions, including immune efficiency (16). Zinc keeps hormone like estrogen, progesterone and testosterone levels stable throughout the entire menstrual cycle. Zinc is reported to be necessary for DNA replication, RNA polymerases, protein synthesis and various metabolic processes. The cell replication, protein synthesis and growth processes etc. are reported to be to some extent dependent upon zinc (17).

It is known that the adult human body have about $1-3 \mathrm{~g}$ of zinc, and about $0.1 \%$ of which is replenished daily ${ }^{(18)}$. 
Zinc insufficiency in the female can lead to complications such as impaired synthesis/secretion of follicle stimulating hormone (FSH) and luteinizing hormone (LH), abnormal ovarian development, estrous cycle disruption, frequent abortion, extended gestation period, teratogenicity, stillbirths, complexity in parturition, pre-eclampsia, toxemia and inferior infant birth weights ${ }^{(19)}$.

Oocytes have shown to express most of the zinc transporters, metallothioneins and metal regulatory transcription factor which may point out a significant role for zinc, in particular with potential linkage toward genome stability during early embryonic development (20).

This study aimed to assess serum zinc level in patients with PCOS.

\section{Methods}

A case-controlled study was conducted in AlImamein Al-Kadhemein Medical City from the period of March to June 2016. Eighty females were enrolled in this study; their age ranged from 20 to 32 years.

Blood samples were obtained from all subjects for serum zinc, serum prolactin (PRL), serum $\mathrm{FSH}$ and serum LH assessments. All subjects had pelvic ultrasonography and body mass index (BMI) measurements.

Exclusion criteria were: chronic or acute medical illnesses, pregnancy, hypothyroidism, and current or previous (within last 2 months) use of any medications known to affect inflammation, anti-diabetic and anti-obesity drugs, insulin or vitamin and mineral supplements.

The subjects were divided into 4 groups:

Group I: Twenty patients with PCOS with BMI ranged from 30.0-40.0

Group II: Twenty normal healthy control obese ladies with BMI ranged from 30.0-40.0

Group III: Twenty patients with PCOS with BMI ranged from 18.5-29.9.

Group IV: Twenty non-obese ladies as a healthy control with BMI ranged from 18.529.9.

\section{Results \\ PCO group vs control group}

Table 1 shows no significant differences in age and in BMI between PCO patients and control group. Serum PRL level was significantly higher in PCO group $(15.07 \pm 8.42)$ than in the control group $(9.19 \pm 2.2)$ with $\mathrm{P}$ value $=0.0001$. Also, serum LH level was significantly higher in PCO group (6.48 \pm 4.36$)$ than in control group $(4.57 \pm 1.8)$ with $P$ value $=0.0123$. There were no significant differences in serum FSH level and serum Zinc level between PCO patients and control group in this study.

Table 1. Comparison between PCO group and control group by unpaired t-test

\begin{tabular}{cccc}
\hline Parameters & $\begin{array}{c}\text { PCO } \\
\mathbf{N}=\mathbf{4 0} \\
\text { Mean } \pm \text { SD }\end{array}$ & $\begin{array}{c}\text { Control } \\
\mathbf{N}=\mathbf{4 0} \\
\text { Mean } \pm \text { SD }\end{array}$ & P value \\
\hline Age $(\mathrm{yr})$ & $25.48 \pm 3.56$ & $25.18 \pm 3.1$ & 0.6889 \\
BMI $\left(\mathrm{kg} / \mathrm{m}^{2}\right)$ & $28.34 \pm 7.17$ & $28.28 \pm 8.33$ & 0.9725 \\
S. PRL $(\mathrm{IU} / \mathrm{ml})$ & $15.07 \pm 8.42$ & $9.19 \pm 2.2$ & 0.0001 \\
S. FSH $(\mathrm{IU} / \mathrm{ml})$ & $4.76 \pm 1.48$ & $4.89 \pm 1.3$ & 0.6689 \\
S. $\mathrm{LH}(\mathrm{IU} / \mathrm{ml})$ & $6.48 \pm 4.36$ & $4.57 \pm 1.8$ & 0.0123 \\
S. Zinc $(\mu \mathrm{g} / \mathrm{dl})$ & $75.31 \pm 33.91$ & $83.8 \pm 10.11$ & 0.1330 \\
\hline
\end{tabular}

\section{Obese PCO group vs obese control group}

There were no significant differences in age and in BMI between obese PCO patients and obese control group in this study. Serum PRL level was significantly higher in obese PCO group (19.57 \pm 9.28$)$ than in obese control group 
(9.54 \pm 2.11$)$ with $P$ value $<0.0001$. Serum $\mathrm{LH}$ level was significantly higher in obese PCO group $(9.84 \pm 3.81)$ than in obese control group $(5.83 \pm 1.63)$ with $P$ value $=0.0001$. Serum zinc level was significantly decreased in obese PCO group $(65.68 \pm 31.28)$ than in obese control group $(82.56 \pm 9.84)$ with $\mathrm{P}$ value $=0.0269$. There was no significant difference in serum FSH level between obese PCO patients and obese control group in this study, (Table 2).

Table 2. Comparison between obese PCO and obese control group by unpaired t-test

\begin{tabular}{cccc}
\hline Parameters & $\begin{array}{c}\text { Obese PCO } \\
\mathbf{N = 2 0} \\
\text { Mean } \pm \text { SD }\end{array}$ & $\begin{array}{c}\text { Obese Control } \\
\mathbf{N = 2 0} \\
\text { Mean } \pm \text { SD }\end{array}$ & P value \\
\hline Age $(\mathrm{yr})$ & $25.6 \pm 3.68$ & $25.55 \pm 3.05$ & 0.9629 \\
BMI $\left(\mathrm{kg} / \mathrm{m}^{2}\right)$ & $35.06 \pm 2.11$ & $35.79 \pm 3.52$ & 0.4711 \\
S. PRL $(\mathrm{IU} / \mathrm{ml})$ & $19.57 \pm 9.28$ & $9.54 \pm 2.11$ & $<0.0001$ \\
S. FSH $(\mathrm{IU} / \mathrm{ml})$ & $4.33 \pm 1.76$ & $4.78 \pm 1.57$ & 0.3971 \\
S. LH $(\mathrm{IU} / \mathrm{ml})$ & $9.84 \pm 3.81$ & $5.83 \pm 1.63$ & 0.0001 \\
S. Zinc $(\mu \mathrm{g} / \mathrm{dl})$ & $65.68 \pm 31.28$ & $82.56 \pm 9.84$ & 0.0269 \\
\hline
\end{tabular}

Non-obese PCO group vs non-obese control group:

There were no significant differences in age, $\mathrm{BMI}$, serum PRL level, serum FSH level, serum
LH level and serum zinc level between nonobese PCOS patients and non-obese control group in this study (Table 3 ).

Table 3. Comparison between non-obese control group and non-obese PCO group by unpaired ttest

\begin{tabular}{cccc}
\hline Parameters & $\begin{array}{c}\text { Non-obese PCO } \\
\mathbf{N = 2 0} \\
\text { Mean } \pm \text { SD }\end{array}$ & $\begin{array}{c}\text { Non-obese Control } \\
\mathbf{N = 2 0} \\
\text { Mean } \pm \text { SD }\end{array}$ & P value \\
\hline Age $(\mathrm{yr})$ & $25.35 \pm 3.53$ & $24.8 \pm 3.19$ & 0.608 \\
BMI $\left(\mathrm{kg} / \mathrm{m}^{2}\right)$ & $21.63 \pm 1.72$ & $20.78 \pm 3.41$ & 0.3288 \\
S. PRL $(\mathrm{IU} / \mathrm{ml})$ & $10.56 \pm 4.08$ & $8.84 \pm 2.28$ & 0.1083 \\
S. FSH $(\mathrm{IU} / \mathrm{ml})$ & $5.18 \pm 1.02$ & $5.0 \pm 1.01$ & 0.5726 \\
S. LH $(\mathrm{IU} / \mathrm{ml})$ & $3.12 \pm 0.86$ & $3.31 \pm 0.82$ & 0.4819 \\
S. Zinc $(\mu \mathrm{g} / \mathrm{dl})$ & $84.94 \pm 34.46$ & $85.05 \pm 10.48$ & 0.9892 \\
\hline
\end{tabular}

Obese control group and non-obese control group

There were no significant differences in age, serum PRL level, serum FSH level and serum zinc level between obese control and nonobese control group in our study. Serum LH level was highly significantly increased in obese control group $(5.83 \pm 1.63)$ than in non-obese control group $(3.31 \pm 0.82)$ with $\mathrm{P}$ value $<0.0001$ as shown in table (4).

Obese PCO group and non-obese PCO group
Table (5) reveals no significant differences in age, serum FSH level and serum zinc level between obese PCO and non-obese PCO groups in this study. Serum PRL level was significant increase in obese PCO group $(19.57 \pm 9.28)$ than in non-obese PCO group $(10.56 \pm 4.08)$ with $P$ value $=0.0003$. Serum $\mathrm{LH}$ level was significantly higher in obese PCO group (9.84 \pm 3.81$)$ than in non-obese PCO group $(3.12 \pm 0.86)$ with $P$ value $<0.0001$. 
Table 4. Comparison between obese control group and non-obese control group by unpaired ttest

\begin{tabular}{|c|c|c|c|}
\hline Parameters & $\begin{array}{c}\text { Obese Control } \\
\mathrm{N}=\mathbf{2 0} \\
\text { Mean } \pm S D\end{array}$ & $\begin{array}{c}\text { Non-obese Control } \\
\mathrm{N}=\mathbf{2 0} \\
\text { Mean } \pm \text { SD }\end{array}$ & $P$ value \\
\hline Age (yr) & $25.55 \pm 3.05$ & $24.8 \pm 3.19$ & 0.452 \\
\hline $\mathrm{BMI}\left(\mathrm{kg} / \mathrm{m}^{2}\right)$ & $35.79 \pm 3.52$ & $20.78 \pm 3.41$ & $<0.0001$ \\
\hline S. PRL (IU/ml) & $9.54 \pm 2.11$ & $8.84 \pm 2.28$ & 0.3199 \\
\hline S. FSH (IU/mI) & $4.78 \pm 1.57$ & $5.0 \pm 1.01$ & 0.597 \\
\hline S. LH (IU/ml) & $5.83 \pm 1.63$ & $3.31 \pm 0.82$ & $<0.0001$ \\
\hline S. Zinc $(\mu \mathrm{g} / \mathrm{dl})$ & $82.56 \pm 9.84$ & $85.05 \pm 10.48$ & 0.4432 \\
\hline
\end{tabular}

Table 5. Comparison between obese PCO group and non-obese PCO group by unpaired t-test

\begin{tabular}{cccc}
\hline Parameters & $\begin{array}{c}\text { Obese PCO } \\
\mathbf{N = 2 0} \\
\text { Mean } \pm \text { SD }\end{array}$ & $\begin{array}{c}\text { Non-obese PCO } \\
\mathbf{N = 2 0} \\
\text { Mean } \pm \text { SD }\end{array}$ & P value \\
\hline Age $(\mathrm{yr})$ & $25.6 \pm 3.68$ & $25.35 \pm 3.53$ & 0.8275 \\
BMI $\left(\mathrm{kg} / \mathrm{m}^{2}\right)$ & $35.06 \pm 2.11$ & $21.63 \pm 1.72$ & $<0.0001$ \\
S. PRL $(\mathrm{IU} / \mathrm{ml})$ & $19.57 \pm 9.28$ & $10.56 \pm 4.08$ & 0.0003 \\
S. FSH $(\mathrm{IU} / \mathrm{ml})$ & $4.33 \pm 1.76$ & $5.18 \pm 1.02$ & 0.0673 \\
S. LH $(\mathrm{IU} / \mathrm{ml})$ & $9.84 \pm 3.81$ & $3.12 \pm 0.86$ & $<0.0001$ \\
S. Zinc $(\mu \mathrm{g} / \mathrm{dl})$ & $65.68 \pm 31.28$ & $84.94 \pm 34.46$ & 0.072 \\
\hline
\end{tabular}

Serum zinc level in the four study groups

Serum zinc level was lowest in obese PCO group in comparison with non-obese PCO, obese control and non-obese groups as shown in figure (1).

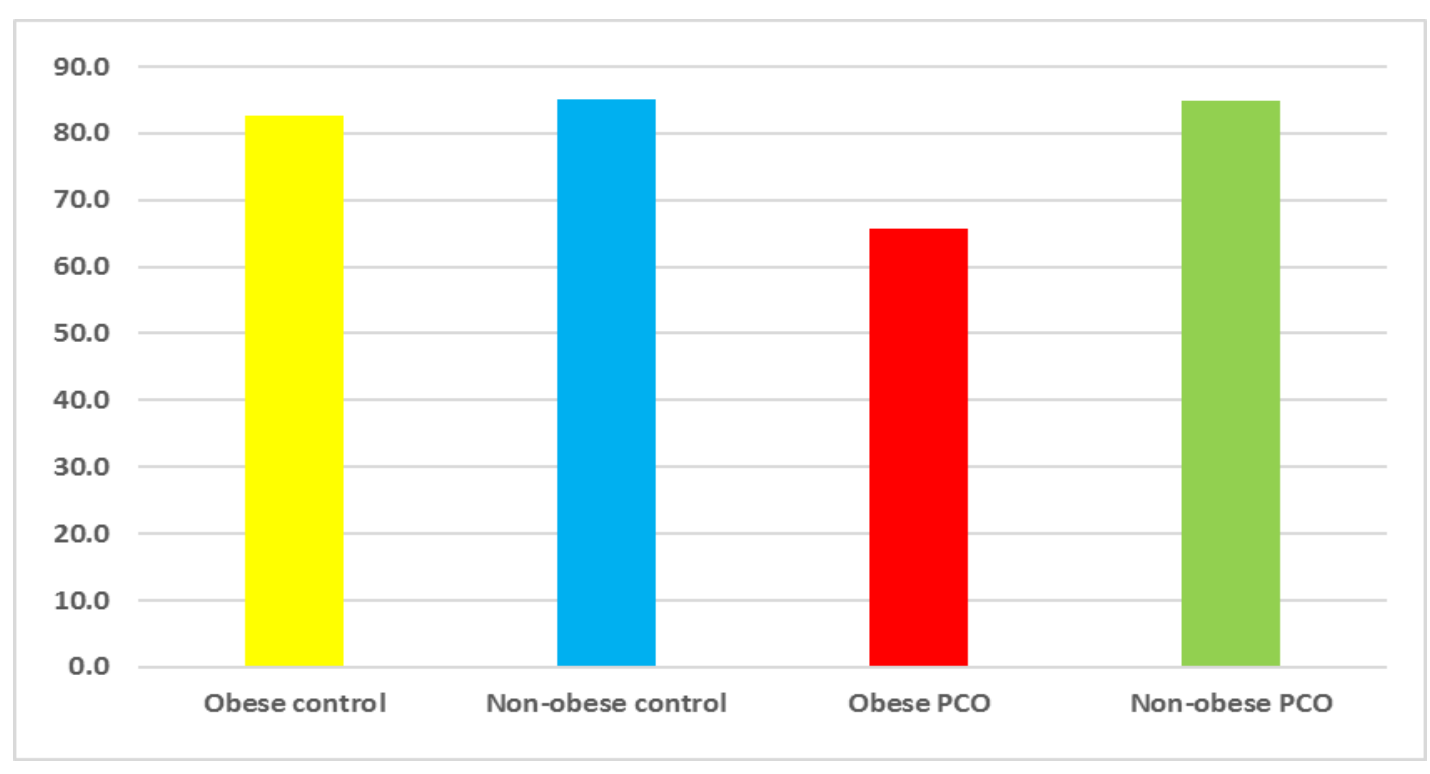

Figure 1. Level of serum zinc in four study groups 
Correlation of serum zinc with other parameters in the four study groups

There was significant negative correlation between serum zinc level and serum PRL level in obese PCO patients. While in non-obese PCO patients, there was significant negative correlation between serum zinc level with BMI and serum PRL as shown in table (6).

Table 6. Correlation of serum zinc with other parameters in the four study groups

\begin{tabular}{|c|c|c|c|c|c|c|c|c|}
\hline \multirow[t]{2}{*}{ Parameters } & \multicolumn{2}{|c|}{$\begin{array}{l}\text { Obese Control } \\
\qquad N=20\end{array}$} & \multicolumn{2}{|c|}{$\begin{array}{c}\text { Non-obese Control } \\
\qquad N=20\end{array}$} & \multicolumn{2}{|c|}{$\begin{array}{c}\text { Obese PCO } \\
\mathbf{N}=\mathbf{2 0}\end{array}$} & \multicolumn{2}{|c|}{$\begin{array}{c}\text { Non-obese PCO } \\
\mathrm{N}=\mathbf{2 0}\end{array}$} \\
\hline & $r$ & $\mathbf{P}$ & $r$ & $\mathbf{P}$ & $r$ & $\mathbf{P}$ & $\mathbf{R}$ & $\mathbf{P}$ \\
\hline Age (yr) & -0.236 & 0.316 & -0.066 & 0.783 & -0.094 & 0.695 & -0.297 & 0.204 \\
\hline $\mathrm{BMI}\left(\mathrm{kg} / \mathrm{m}^{2}\right)$ & -0.196 & 0.408 & -0.048 & 0.842 & -0.558 & 0.010 & -0.646 & 0.002 \\
\hline S. PRL (IU/ml) & 0.032 & 0.895 & -0.176 & 0.457 & -0.097 & 0.684 & -0.539 & 0.014 \\
\hline S. FSH (IU/ml) & 0.239 & 0.311 & 0.226 & 0.337 & -0.021 & 0.928 & -0.223 & 0.345 \\
\hline S. LH (IU/ml) & 0.326 & 0.161 & -0.337 & 0.146 & 0.179 & 0.449 & -0.080 & 0.736 \\
\hline
\end{tabular}

Correlation of serum zinc with other parameters in control and PCO groups

There was significant negative correlation between serum zinc level with BMI and serum
PRL level in PCO patients, which was not significant in control group as shown in table (7).

Table 7. Correlation of serum zinc with other parameters in control and PCO groups

\begin{tabular}{ccccc}
\hline & \multicolumn{3}{c}{ Control } \\
N=40 & & \multicolumn{3}{c}{ PCO } \\
Narameters & $\mathbf{r}$ & $\mathbf{P}$ & $\mathbf{r}$ & $\mathbf{P}$ \\
\hline Age $(\mathrm{yr})$ & -0.160 & 0.325 & -0.199 & 0.217 \\
BMI $\left(\mathrm{kg} / \mathrm{m}^{2}\right)$ & -0.172 & 0.289 & -0.445 & 0.004 \\
S. PRL $(\mathrm{IU} / \mathrm{ml})$ & 0.098 & 0.547 & -0.334 & 0.035 \\
S. FSH $(\mathrm{IU} / \mathrm{ml})$ & 0.235 & 0.145 & -0.003 & 0.984 \\
S. LH $(\mathrm{IU} / \mathrm{ml})$ & -0.026 & 0.875 & -0.162 & 0.318 \\
\hline
\end{tabular}

\section{Discussion}

Polycystic ovary syndrome is the most common endocrine-metabolic disorder. It can be defined as a combination of hyperandrogenism (hirsutism and acne) and anovulation (oligomenorrhea, infertility, and dysfunctional uterine bleeding) with polycystic ovaries ${ }^{(1)}$.

Serum PRL level was significantly higher in PCO group than in control group with $P$ value < 0.0001 , which is consistent with other study (21). This increased PRL level may augment adrenal androgen secretion by the inhibition of 3-betahydroxysteroid dehydrogenase activity or, less often, through selective action on the sulfation of DHEA in adrenal or extra-adrenal sites. However, PRL inhibits FSH-induced ovarian aromatase, leading to intraovarian hyperandrogenemia ${ }^{(22)}$. Serum LH level was significantly increased in PCO group than in control group with $P$ value $<0.01$, which is consistent with other study ${ }^{(23)}$.

Serum PRL level and serum LH level in obese PCO group were highly significantly increased compared to obese control group with $\mathrm{P}$ value $<0.0001$ in which, they were consistent with other study ${ }^{(24)}$. It can be explained due to abnormality of the hypothalamic-pituitary ovarian or adrenal axis has been implicated in PCOS. Disturbance in gonadotrophin releasing hormone $(\mathrm{GnRH})$ results in the relative increase 
in LH to FSH release, abnormal feedback mechanism by ovarian estrogen is blamed to play role in this discriminated increase in $\mathrm{LH}$ release ${ }^{(25)}$.

Serum zinc level was significantly decreased in obese PCO group than in obese control group with $P$ value $<0.02$, which is different from other study which showed no significant difference between patients group and control group with respect to serum zinc levels $(P>$ $0.05)^{(26)}$.

One of the possible mechanisms of zinc relationship to PCOS other than insulin signaling system defects may be its effect on oxidative stress, zinc is a potent antioxidant and its deficiency causes increased oxidative damage in multiple organs, including the heart (27).

Oxidative stress induces infertility in women through a variety of mechanisms. Excess reactive oxygen species (ROS) in the follicle may overwhelm follicular fluid antioxidant defense and directly damage oocytes. The DNA of oocytes and spermatozoa may be damaged, leading to defective fertilization when the peritoneal cavity microenvironment is plagued with severe oxidative stress. Even when fertilization is achieved, oxidative stressinduced apoptosis may result in embryo fragmentation, implantation failure, abortion, impaired placentation, and congenital abnormalities ${ }^{(28)}$.

Excess ROS may hinder the endometrium, which normally functions to support the embryo and its development (29). Oxidative stress may induce luteal regression and insufficient luteal hormonal support for the continuation of a pregnancy ${ }^{(30)}$.

Non-obese PCO patients without insulin resistance also have been reported to have elevated total oxidant and antioxidant status. Verit et al. demonstrated that total antioxidant status in these types of PCO patients was correlated with raised LH levels and free androgen and dehydroepiandrosterone (DHEAS) levels (31).
There was significant negative correlation between serum zinc level and BMI in PCO patients. It has been found that BMI and PRL are all inversely associated with arsenic, cadmium, copper, lead, manganese, molybdenum, and $\mathrm{Zn} \mathrm{(32).} \mathrm{Obese} \mathrm{individuals}$ have lower blood concentrations of some vitamins and minerals compared to non-obese individuals ${ }^{(33)}$. Also, it has been observed that zinc concentration is directly associated with serum leptin concentration (34). So leptin resistance that occurred in obesity might have resulted from zinc deficiency in which, zinc may either directly affect leptin gene expression or indirectly cause leptin production by increasing glucose use of the fatty tissue. Also, there was significant negative correlation between serum zinc level and serum PRL level in non-obese PCO patients. This had been shown in a wide number of in vitro studies in which, an inverse relationship between zinc and PRL. Zinc interferes physiologically and pharmacologically in the synthesis, storage, release and peripheral action of PRL. Interaction with calcium-channels, calciumcalmodulin complex, adenylate cyclase, secretory granules, membrane stabilization and membrane receptors are some of proposed mechanisms of Zinc involvement in PRL secretion, as was reviewed by Brando-Neto et al (35).

It is concluded that serum zinc level reduced in obese PCO than in non-obese PCO. The level of serum zinc is negatively correlated with BMI and serum PRL level.

\section{Acknowledgments}

Great thanks to Dr. Batool H. Al-Musawi for her unlimited help in collection of patients. Also my thanks to Dr. Majid H. Ahmed for his effort in doing statistics.

\section{Conflict of interest}

There is no conflict of interest.

Funding

Self-funding. 


\section{References}

1. Christensen SB, Black MH, Smith $\mathrm{N}$, et al. Prevalence of polycystic ovary syndrome in adolescents. Fertil Steril. 2013, 100(2), 470-7. doi: 10.1016/j.fertnstert.2013.04.001.

2. Hwang KR, Choi YM, Kim JJ, et al. Effects of insulinsensitizing agents and insulin resistance in women with polycystic ovary syndrome. Clin Exp Reprod Med 2013, 40(2): 100-5. doi: 10.5653/cerm.2013.40.2.100.

3. Alvarez-Blasco F, Botella-Carretero JI, San Millan JL, et al. Prevalence and characteristics of the polycystic ovary syndrome in overweight and obese women, Arch Intern Med. 2006; 166, 2081-6. doi: 10.1001/archinte.166.19.2081.

4. Witchel S. Puberty and polycystic ovary syndrome. Mol Cel Endocrinol. 2006; 254-255: 146-53. doi: 10.1016/j.mce.2006.04.028.

5. Jakubowski L. Genetic aspects of polycystic ovary syndrome. Endokrynol Pol. 2005; 56, 285-93.

6. Carmina E. Cardiovascular risk \& events in polycystic ovary syndrome. Climacteric. 2009; 12(Suppl 1): 22-5. doi: 10.1080/13697130903003842.

7. Pasquali R, Gambineri A, Pagotto U. The impact of obesity on reproduction in women with polycystic ovary syndrome. BJOG 2006; 113: 1148-59. doi: 10.1111/j.1471-0528.2006.00990.x.

8. Diamanti-Kandarakis $\mathrm{E}$, Paterakis $\mathrm{T}$, Alexandraki K, et al. Indices of low-grade chronic inflammation in polycystic ovary syndrome and the beneficial effect of metformin. Hum Reprod. 2006; 21: 1426-31. doi: 10.1093/humrep/del003.

9. Essah PA, Wickham III EP, Nunley JR, et al. Dermatology of androgen-related disorders. Clin Dermatol. 2006; 24(4): 289-98. doi: 10.1016/j.clindermatol.2006.04.004.

10. Redmond GP, Bergfeld WF. Diagnostic approach to androgen disorders in women: acne, hirsutism, and alopecia. Cleveland Clin J Med. 1990; 57(5): 423-7. doi: 10.3949/ccjm.57.5.423.

11. Escobar-Morreale HF, Carmina E, Dewailly D, et al. Epidemiology, diagnosis and management of hirsutism: a consensus statement by the androgen excess and polycystic ovary syndrome society. Hum Reprod Update. 2012; 18(2): 146-70. doi: 10.1093/humupd/dmr042.

12. Zouboulis CC. Acne and sebaceous gland function. Clin Dermatol. 2004; 22(5): 360-6. doi: 10.1016/j.clindermatol.2004.03.004.

13. Price VH. Androgenetic alopecia in women. J Invest Dermatol Symp Proc. 2003; 8(1): 24-7. doi: 10.1046/j.1523-1747.2003.12168.x.

14. Rotterdam ESHRE/ASRM-Sponsored PCOS Consensus Workshop Group. Revised 2003 consensus on diagnostic criteria and long-term health risks related to polycystic ovary syndrome (PCOS). Hum Reprod 2004; 19: 41-7. doi: https://doi.org/10.1093/humrep/deh098.

15. Prasad AS. Zinc: mechanisms of host defense. J Nutr. 2007; 137(5): 1345-9.
16. Rink L, Kirchner $\mathrm{H}$. Zinc-altered immune function and cytokine production. J Nutr. 2000; 130: 1407S-11S.

17. Environmental Health Criteria (EHC). Zinc. IPCS INCHEM. 2001; 221. Available at: http://www.inchem.org/documents/ehc/ehc/ehc221 .htm

18. Maret W, Sandstead $\mathrm{HH}$. Zinc requirements and the risks and benefits of zinc supplementation. J Trace Elem Med Biol. 2006; 20: 3-18. doi: 10.1016/j.jtemb.2006.01.006.

19. Bedwal RS, Bahuguna A. Zinc, copper and selenium in reproduction. Experientia. 1994; 50: 626-40. doi: 10.1007/BF01952862.

20. Ménézo $Y$, Pluntz L, Chouteau J, et al. Zinc concentrations in serum and follicular fluid during ovarian stimulation and expression of $\mathrm{Zn} 2 \pm$ transporters in human oocytes and cumulus cells. Reprod Biomed Online. 2011; 22: 647-52. doi: 10.1016/j.rbmo.2011.03.015.

21.Zandi S, Farajzadeh S, Safari H. Prevalence of polycystic ovary syndrome in women with acne: hormone profiles and clinical findings. J Pakistan Ass Dermatol. 2010; 20: 194-8.

22. Roy George K, Malini NA. The prevalence and etiology of polycystic ovarian syndrome (PCOS) as a cause of female infertility in central Travancore. The Bioscan. 2014; 9(1): 1-6.

23. Anlakash $\mathrm{AH}$. Polycystic ovarian syndrome-the correlation between $\mathrm{LH} / \mathrm{FSH}$ ratio and disease manifestation. Middle East Fertil Soc J. 2007; 12(1): 35-40.

24. Richard SL, Ricardo A. Androgen excess disorders. Danforth's obstetrics and gynecology. 8th ed. Philadelphia: Lippincott Williams \& Wilkins; 2003. p. 663-72.

25. McKenna TJ. Pathogenesis and treatment of polycystic ovary syndrome. N Engl J Med. 1988; 318: 558-62. doi: 10.1056/NEJM198803033180906.

26. Sohrabvand F, Shirazi $M$, Shariat $M$, et al. Serum zinc level in infertile women with and without polycystic ovary syndrome: a comparative study. Tehran Univ Med J. 2013; 71(3): 157-63.

27. Guler I. Zinc and homocysteine levels in polycystic ovarian syndrome patients with insulin resistance. Biol Trace Elem Res. 2014; 158(3): 297-304. doi: 10.1007/s12011-014-9941-7.

28. Agarwal A, Said TM, Bedaiwy MA, et al. Oxidative stress in an assisted reproductive techniques' setting. Fertil Steril 2006; 86(3): 503-12. doi: 10.1016/j.fertnstert.2006.02.088.

29. Iborra A, Palacio JR, Martinez P. Oxidative stress and autoimmune response in the infertile woman. Chem Immunol Allergy. 2005; 88: 150-62. doi: 10.1159/000087832.

30. Agarwal A, Allamaneni S. Role of free radicals in female reproductive diseases and assisted reproduction. Reprod Biomed. 2004; 9(3): 338-47. doi: 10.1016/S1472-6483(10)62151-7.

31. Verit FF, Erel O. Oxidative stress in nonobese women with polycystic ovary syndrome: correlations with 
endocrine and screening parameters. Gynecol Obstet Invest. 2008; 65(4): 233-9. doi: 10.1159/000113046.

32. Meeker JD, Rossano MG, Protas B, et al. Multiple metals predict prolactin and thyrotropin (TSH) levels in men. Environ Res. 2009; 109(7): 869-73. doi: 10.1016/j.envres.2009.06.004.

33. Singh RB, Beegom R, Rastogi SS, et al. Association of low plasma concentrations of antioxidant vitamins, magnesium and zinc with high body fat per cent measured by bioelectrical impedance analysis in Indian men. Magnes Res. 1998, 11(1): 3-10.

34. Mantzoros CS, Prasad AS, Beck FW, et al. Zinc may regulate serum leptin concentrations in humans. J
Am Coll Nutr. 1998, 17(3): 270-5. doi: 10.1080/07315724.1998.10718758.

35. Brando-Neto J, Mduriera G, Mendonca BB, et al. Endocrine interaction between and zinc and prolactin. An interpretive review. Biol Trace Elem Res. 1995; 49: 139-49. doi: 10.1007/BF02788963.

\section{E-mail: driqbalderma30@gmail.com Received 4 ${ }^{\text {th }}$ Oct. 2016 Accepted 10 $0^{\text {th }}$ Jan. 2017}

